JPPUMA: Jurnal Ilmu Pemerintahan dan Sosial Politik UMA (Journal of Governance and Political Social UMA), 7 (1) (2019): 30-39

JPPUMA: Jurnal Ilmu Pemerintahan dan Sosial Politik UMA

(Journal of Governance and Political Social UMA)

DOI: http://dx.doi.org/10.31289/ippuma.v7i1.2174

Available online http://ojs.uma.ac.id/index.php/jppuma

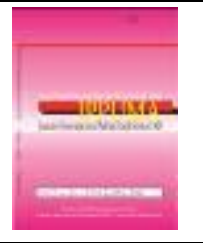

\title{
Perbandingan Model Therapeutic Community (TC) dan Narcotics Anonymous (NA) di Pelayanan Kesejahteraan Sosial Adiksi Narkoba
}

\section{Comparison of Therapeutic Community (TC) and Narcotics Anonymous (NA) Models in Drug Addiction Social Welfare Services}

\author{
Fajar Utama Ritonga* \& Adil Arifin
}

\begin{abstract}
1. Program Studi Ilmu Kesejahteraan Sosial, Fakultas Ilmu Sosial dan Ilmu Politik Universitas Sumatera Utara, Indonesia
2.. Program Studi Ilmu Politik, Fakultas Ilmu Sosial dan Ilmu Politik Universitas Sumatera Utara, Indonesia
\end{abstract}

Diterima Maret 2019; Disetujui Mei 2019; Dipublikasikan Juni 2019

\section{Abstrak}

Penelitian ini membandingkan model Therapeutic Community dengan Model Narcotics Anonymous yang diterapkan panti rehabilitasi Narkotika, Psikotropika dan Obat Terlarang (Narkoba) dalam meningkatkan partisipasi residen. Pendekatan penelitian yang digunakan adalah kualitatif dengan jenis deskriptif. Lokasi penelitian dilakukan di Panti Charitas PSE Kabupaten Deliserdang, Yayasan Mitra Masyarakat Kota Medan yang menggunakan Model Narcotics Anonymous. Panti Rehabiliasi Narkoba menggunakan Model Therapeutic Community yaitu: Panti Sosial Permadi Putra (PSPP) Insyaf Kabupaten Deliserdang, Yayasan Nazar Kota Medan, LOKA BNN Deliserdang. Populasi dalam penelitian ini adalah keseluruhan residen yang berada di Panti Rehabilitasi yang menjadi lokasi penelitian sebanyak 114 orang, sampel penelitianiniadalah keseluruhan populasi penelitian dengan rumus $\mathrm{n}=\mathrm{N}$ maka sampel penelitian ini berjumlah 114 orang. Teknik pengumpulan data melalui studi literatur, wawancara dan kuesioner, serta observasi lapangan. Hasil penelitian menunjukkan dari 7 tahapan model partisipasi yang digunakan terdapat perbedaan pada tahapan Partisipasi Fungsional menggunakan Model Therapuetic Community (TC) 55,5\%, sedangkan Model Narcotic Anonymous (NA) adalah 100\%, pada tahap ini perbedaan sangat signifikan sebesar 44,5\%, dan Partisipasi interaktif menggunakan Model Therapeutic Community (TC) 65,4"\%, sedangkan Model Narcotic Anonymous (NA) adalah 44\%, pada tahap ini terjadi perbedaan sebesar $21,5 \%$

Kata kunci:, Perbandingan, Mode Therapeutic Community Dan Model Narcotic's Anonymous

\section{Abstract}

This study compares the Therapeutic Community model with the Narcotics Anonymous Model which is applied to the Narkotika, Psikotropika dan Obat Terlarang (Narkoba) institutions in increasing resident participation. The research approach used is qualitative with descriptive type. The location of the study was conducted at the Charitas PSE Institution in Deliserdang Regency, Medan Mitra Masyarakat Foundation, which used the Narcotics Anonymous Model. The Narcotics Rehabilitation Institution uses the Therapeutic Community Model, namely: Panti Sosial Permadi Putra (PSPP) Initiated by Deliserdang District, Yayasan Nazar Medan City, LOKA BNN Deliserdang. The population in this study is the entire resident who is in the Rehabilitation Institution which is the location of the study as many as 114 people, the sample of this study is the entire study population with the formula $n=N$, the sample of this study amounted to 114 people. Techniques for collecting data through literature studies, interview and questionnaires, and field observations. The results showed that from the 7 stages of the participation model used there were differences in the Functional Participation stage using the Therapuetic Community Model (TC) 55.5 "\%, while the Narcotic Anonymous (NA) Model was 100\%, at this stage the difference was very significant at $44.5 \%$, and interactive participation using Therapeutic Community Model (TC) 65.4\%, while Narcotic Anonymous Model (NA) is 44\%, at this stage there is a difference of $21.5 \%$

Keywords: Comparison, Therapeutic Community Model and Narcotic's Anonymous Model

How to Cite: Ritonga, F.U. \& Arifin, A. (2019). Perbandingan Model Therapeutic Community (TC) dan Narcotics Anonymous (NA) di Pelayanan Kesejahteraan Sosial Adiksi Narkoba. JPPUMA: Jurnal Ilmu Pemerintahan dan Sosial Politik UMA (Journal of Governance and Political Social UMA), 7 (1): 30-39

*Corresponding author:

ISSN 2549-1660 (Print)

E-mail: fajar1utama5@gmail.com

ISSN 2550-1305 (Online) 


\section{PENDAHULUAN}

Sampai saat ini dikenal 2 model populer Pelayanan Kesejahteraan Sosial Rehabilitasi Narkoba, model pertama adalah Model Therapeutic Comunity (TC) dan model ke dua adalah Model Narcotics Anonymous. Kedua model ini cenderung menjadi patokan pengelola Panti Rehabilitasi, konselor, pekerja sosial, dalam memberikan pelayanan di Panti Rehabilitasi Narkotika, Psikotropika dan Obat Terlarang ( Narkoba).

Konsep Therapeutic Community (TC) yaitu menolong diri sendiri, dapat dilakukan dengan adanya keyakinan bahwa: 1. Setiap orang bisa berubah. 2 . Kelompok mendukung untuk berubah. 3 . Setiap individu harus bertanggung jawab. 4. Program terstruktur dapat menyediakan lingkungan aman dan kondusif bagi perubahan. 5. Adanya partisipasi aktif. (Maharani, 2018)

Konsep 5 pilar yang dianut dalam Therapeutic Community (TC). Adalah: a. Family milieu concept (Konsep kekeluargaan). b. Peer pressure (Tekanan rekan sebaya. c. Therapeutic session (Sesi terapi). d. Religius session (Sesi agama). e. Role modelling (Keteladanan) (Herlina, 2016)

Hasil penelitian yang dilakukan Espanosa dkk tahun 2018 dengan judul Psychological Intervention for Development of Disease Awareness in Addicts: Villa Colibri Therapeutic Community of Santiago de Cuba menunjukkan hasil The Psychological Intervention Program was developed, based on the cognitivebehavioral model with a humanistic approach. with respect to the attitude towards the disease, the subjects predominated in ambivalence in $70.6 \%$ and non-consciousness in $23.5 \%$, referring to interpersonal relationships, ambivalent in $58.8 \%$ and not healthy in $29.4 \%$ and conflict management was inconsistent in $70.6 \%$, and inadequate in $23.5 \%$, after the development of the program, positive attitude increased $52.9 \%$ and ambivalence decreased to $41.2 \%$, healthy interpersonal relationships grew to $47.1 \%$ and adequate conflict management was imposed in 58.8\% of the sample. The lack of awareness of the disease in patients was identified, the preliminary results of the application of the program proved to be very useful to develop awareness of the disease in the subjects studied, thus achieving a better therapeutic adherence

Narcotics Anonymous (NA) yaitu sebuah kelompok pemulihan dengan fokus untuk bersih dari narkoba. Kelompok ini dikenal dengan sebutan "kelompok bantu diri". Cara kerja kelompok ini didasarkan pada prinsip 12 langkah. (Pimansu, 2010)

Hasil penelitian yang dilakukan Erma 2016) dengan judul Pendekatan Metode Narcotics Anonymous Dalam Pemulihan Korban Penyalahgunaan Narkoba Di Yayasan Lingkaran Harapan Banua Banjarmasin, menunjukkan bahwa: 1 . Metode Narcotics Anonymous ini sangat menekankan rasa kekeluargaan dan perasaan senasib sepenanggungan, 2 . Tingkat partisipasi korban yang mengikuti metode Narcotics Anonymous ini cukup tinggi, 3. Metode Narcotics Anonymous punya dukungan kuat terhadap pemulihan korban penyalahgunaan narkoba, 4 . Narcotics Anonymous ini sangat membantu korban penyalah guna dalam memperbaiki hubungan dengan keluarga, serta mendapatkan kembali kepercayaan yang telah hilang dari keluarga juga meningkatkan kepercayaan terhadap diri sendiri.

Penelitian ini fokus kepada proses partisipasi residen selama menjalani rehabilitasi yang menggunakan Model Therapeutic Comunity (TC) dan Model Narcotics Anonymous (NA).

Tujuan penelitian ini adalah membandingkan Model Therapeutic Community (TC) dan Model Narcotic's Anonymous dalam meningkatkan partisipasi residen di pelayanan rehabilitasi narkoba.

Hal ini dapat menjadi awal investigasi atas banyaknya kasus-kasus relapse (korban pengguna narkoba yang kambuh setelah 
keluar dari program rehabilitasi narkotika, psikotropika, dan obat terlarang), karena selama ini hanya faktor-faktor diluar panti yang menjadi perhatian para peneliti, jarang sekali para peneliti melihat progres berjalannya program rehabilitasi yang dilakukan oleh panti rehabilitiasi dalam upaya penyembuhan ketergantungan Narkotika, Psikotropika, dan Obat Terlarang (Narkoba).

\section{METODE PENELITIAN}

Penelitian ini menggunakan pendekatan kualitatif dengan jenis penelitian deskriptif yang bertujuan menggambarakan perubahan tingkat partisipasi residen narkoba dalam setiap program yang dijalankan panti rehabilitasi narkoba Model Therapeutic Community dan Model Narcotics Anonymous. Lokasi penelitian ini adalah panti rehabilitasi yang menggunakan model Narcotic Anonymous yaitu Panti Charitas PSE Kabupaten Deli Serdang, Yayasan Mitra Masyarakat Kota Medan. Panti Rehabiliasi Narkoba menggunakan Model Therapeutic Community yaitu: Panti Sosial Permadi Putra (PSPP) Insyaf Kabupaten Deli serdang, Yayasan Nazar Kota Medan, LOKA BNN Deliserdang.

Populasi dalam penelitian ini adalah keseluruhan residen yang berada di Panti Rehabilitasi yang menjadi lokasi penelitian sebanyak 114 orang, sampel penelitian ini adalah keseluruhan populasi penelitian dengan rumus $\mathrm{n}=\mathrm{N}$ (Moleong, 2010), maka sampel penelitian ini berjumlah 114 orang.

Teknik pengumpulan data melalui studi literatur, wawancara dan kueisoner, serta observasi lapangan, wawancara menggunakan pendekatan purpossive sampling (sampling bertujuan) dalam penelitian ini adalah informan kunci yaitu pengelola panti rehabilitasi sebanyak 5 orang dan informan utama yaitu konselor/pekerja sosial di setiap panti sebanyak 7 orang, teknik analisis data menggunakan teknik analisis data kualitatif.

\section{HASIL DAN PEMBAHASAN}

Hasil penelitian yang telah diolah peneliti menggunakan bantuan software SPSS versi 23. Indikator yang digunakan peneliti untuk menggambarkan peningkatan partisipasi residen menurut Prety, J., 1995 dalam (Syahyuti, 2016) ada tujuh karakteristik tipologi partisipasi, yang berturut-turut semakin dekat kepada bentuk yang ideal, yaitu: 1. Partisipasi pasif atau manipulatif., 2. Partisipasi informative, 3. Partisipasi konsultatif, 4. Partisipasi insentif 5. Partisipasi fungsional, 6. Partisipasi interaktif, 7. Mandiri (self mobilization) (Syahyuti, 2016) Perbandingan peningkatan partisipasi residen dalam mengikuti program rehabilitasi narkoba yang diselenggarakan oleh panti rehabilitasi narkoba menggunakan Model Therapeutic Community (TC) dan Narcotic Anonymuos (NA) sebagai berikut:

Tabel 1 Tahap 1 "partisipasi pasif atau manipulatif" saat awal masuk responden mengikuti semua perintah konselor tanpa diberikan hak untuk bertanya

\begin{tabular}{lcc}
\hline Keterangan & Frekuensi & Persen \\
\hline Tidak Setuju & 10 & 8.8 \\
\hline Kurang Setuju & 14 & 12.3 \\
\hline Setuju & 90 & 78.9 \\
\hline Total & 114 & 100.0
\end{tabular}

Sumber: Hasil olah data penelitian, 2018

Hal ini menggambarkan bahwa pada saat awal masuk partisipasi pasif atau manipulatif terjadi lebih besar kepada residen, dikarenakan para residen tidak dapat berkomunikasi dengan intensif kepada konselor/pekerja sosial dan residen hanya menurut saja tanpa sadar semua arahan atau perintah dari konselor/pekerja sosial. Kondisi tersebut berbeda dengan residen yang mengatakan tidak setuju sebanyak 10 orang atau 8,8\%, dan responden yang menyatakan kurang setuju sebanyak 14 orang atau $12,3 \%$. Hal ini dikarenakan residen merasa tidak nyaman dengan program panti saat awal masuk, kemudian merasa bosan, tidak bebas beraktifitas karena harus mengikuti program yang dijadwalkan panti rehabilitasi. 
Hasil penelitian tersebut didukung oleh hasil wawancara peneliti dengan informan kunci sebagai berikut:

"karena memang kita sadari mereka yang masuk ini tidak semuanya karena kesadaran mereka ingin sembuh memakai narkoba, jadi mereka di awal masuk hanya ikut saja dengan kondisi di panti rehabilitasi, kalau kita lihat yang masuk ke panti ini karena ditangkap polisi, BNN, maupun paksaan orang tua, istri, keluarga, macam-macamlah motifnya"

Menurut informan kunci lainnya sebagai berikut:

$$
\text { "tergantung dari tingkat }
$$

keparahannya residen, kalau dia masih pada tahap coba-coba belum terlalu ketergantungan menggunnakan narkoba istilah kita tahap primary, kemungkinan besar dia tidak melawan sampai melarikan diri tidak ada itu. Tetapi kalau sudah sampai tahap akut dan dia harus dikontrol dengan medis panti juga tidak mampu menanganinya, karena bisa merusak program yang kita jalankan disini dan tentunya bisa mempengaruhi kelompok teman-teman lainnya yang menjalankan program."

Kondisi tersebut didukung oleh hasil wawancara penelitian dengan informan utama sebagai berikut:

"berdasarkan pengalaman saya sebagai konselor memang yang masuk panti ini pada awalnya hanya ikut apa perintah konselor, karena masih baru, kemudian mengikuti peraturan atau SOP dari panti rehabilitasi. Kebanyakan dari residen tersebut hanya ikut saja tapi ada juga memang yang melakukan resistensi (perlawanan) untuk hal tersebut pendekatan yang kita lakukan tentunya tidak sama dengan residen yang mengikuti perintah atau arahan dari konselor"
Tabel 2. Nama Panti * Pada saat awal masuk responden mengikuti semua perintah konselor tanpa diberikan hak untuk bertanya Crosstabulation

Pada saat awal masuk responden mengikuti semua perintah konselor tanpa diberikan hak untuk bertanya

\begin{tabular}{llccc}
\hline $\begin{array}{l}\text { Panti } \\
\text { Rehabilitasi }\end{array}$ & $\begin{array}{c}\text { Tidak } \\
\text { Setuju }\end{array}$ & $\begin{array}{c}\text { Kurang } \\
\text { Setuju }\end{array}$ & Setuju & Total \\
\hline YAMIMAS & 1 & 0 & 5 & 6 \\
\hline CARITAS & 4 & 3 & 12 & 19 \\
\hline PERMADI & 0 & 1 & 26 & 27 \\
\hline NAZAR & 3 & 7 & 39 & 49 \\
\hline Total & 8 & 11 & 82 & 101 \\
\hline
\end{tabular}

Sumber: Hasil olah data penelitian, 2018

Tabel 3. Tahap Ke 2 Terjadi Komunikasi antara residen dengan konselor/peksos/petugas panti

\begin{tabular}{lcc}
\hline Keterangan & Frekuensi & Persen \\
\hline Tidak Menjawab & 4 & 3.5 \\
\hline Kurang Setuju & 7 & 6.1 \\
\hline Setuju & 103 & 90.4 \\
\hline Total & 114 & 100.0 \\
\hline
\end{tabular}

Sumber: Hasil olah data penelitian, 2018

Hal ini menggambarkan bahwa pada tahap ke 2 telah terjalin komunikasi antara residen yang baru masuk dengan pekerja sosial, komunikasi pada tahap ini adalah komunikasi awal seperti sapaan (say hello), perbincangan yang umumnya terjadi antara orang yang baru berkenalan.

Hasil penelitian tersebut didukung oleh hasil wawancara peneliti dengan informan kunci sebagai berikut:

"Komunikasi merupakan hal yang penting dilakukan setelah mereka masuk di panti rehabilitasi biasanya setelah selesai tahapan pemeriksaan medis atau detoksifikasi. Langkah tersebut sebenarnya sebagai modal awal konselor/pekerja sosial menjalin relasi dengan residen."

Menurut informan kunci lainnya sebagai berikut:

"Komunikasi antara konselor atau pekerja sosial dengan residen menurut saya langkah awal memulai tahapan assessment, membangun kepercayaan antara residen dengan konselor, membangun hubungan kekeluargaan. Untuk itu tahapan ini penting dilakukan dan biasanya residen sudah mau berkomunikasi atau menjalin 
Fajar Utama Ritonga \& Adil Arifin, Perbandingan Model Therapeutic Community (TC)

hubungan dengan konselor, karena memang sudah tugas konselor untuk deluan memulai kommunikasi tersebut"

Hal tersebut diperkuat dari hasil wawancara informan utama sebagai berikut:

"Komunikasi kita terus jalin dengan residen karena ini tahap awal kita bekerja sama dengan mereka selama mereka menjalani program rehabilitasi narkoba disini. Kebanyakan dari mereka sudah mau berkomunikasi dengan pekerja sosial namun masih ada yang menutup diri, hal ini hanyalah masalah waktu saja karena kita terus menjalin komunikasi dengan mereka".

Tabel 4. Terjadinya tahap ke 3

Tahap ke 3 terjalin komunikasi yang lebih intens antara residen dengan konselor/peksos/petugas panti

\begin{tabular}{lll}
\hline Keterangan & Frekuensi & Persen \\
\hline Tidak Menjawab & 3 & 2.6 \\
\hline Kurang Setuju & 17 & 14.9 \\
\hline Setuju & 94 & 82.5 \\
\hline Total & 114 & 100.0 \\
\hline
\end{tabular}

Sumber: Hasil olah data penelitian, 2018

Pada tahap ke 3 (partisipasi konsultatif) dari tabel di atas dapat dilihat bahwa mayoritas responden sebanyak 94 orang atau $82,5 \%$ menyatakan setuju bahwa terjalin komunnikasi lebih intens antara residen dengan konselor/pekerja sosial/petugas panti.

Hal ini menggambarkan bahwa pada tahap ke 3 telah terjalin komunikasi lebih intens antara residen dengan pekerja sosial, komunikasi pada tahap ini biasanya dilakukan dengan sesi morning meeting, residen mencurahkan isi hatinya, pengalaman selama berada di panti rehabilitasi dan konselor/pekerja sosial sebagai media menampung curahan hati residen sekaligus sebagai penyemangat dan memberikan motivasi untuk tetap mengikuti program rehabilitasi.

Hasil penelitian tersebut didukung oleh hasil wawancara peneliti dengan informan kunci sebagai berikut:

"dibutuhkan waktu agar residen mau terbuka secara keseluruhan, karena memang tidak semua residen ini bisa berhasil secara merata. Mungkin perlu dilakukan pendekatan lebih intens dari pekerja sosial/konselor"

Menurut informan kunci lainnya sebagai berikut:

"Tidak mudah memang menjalin komunikasi lebih intens kepada residen, tapi biasanya jika sudah bisa menjalin komunikasi intens posisi mereka (residen) sudah lebih dekat seperti keluarga saja mereka disini, dan lebih enjoy menjalani program rehabilitasi".

Menurut informan kunci lainnya sebagai berikut:

"Itulah salah satu tugas yang harus dilakukan pekerja sosial dan harus berhasil melakukan tersebut, karena kalau mereka bellum bisa menerima pekerja sosial/konselor kedepannya mereka akan sulit partisipasi mengikuti program rehabilitasi".

Tabel 5. Tahap ke 3 Partisipasi responden meningkat setelah terjadi komunikasi antara residen dengan konselor setelah komunikasi intens/tahap 3

Pada saat awal masuk responden mengikuti semua perintah konselor tanpa diberikan hak untuk bertanya

\begin{tabular}{llccc}
\hline $\begin{array}{c}\text { Panti } \\
\text { Rehabilitasi }\end{array}$ & $\begin{array}{c}\text { Tidak } \\
\text { Setuju }\end{array}$ & $\begin{array}{c}\text { Kurang } \\
\text { Setuju }\end{array}$ & Setuju & Total \\
\hline YAMIMAS & 1 & 0 & 5 & 6 \\
\hline CARITAS & 4 & 3 & 12 & 19 \\
\hline PERMADI & 0 & 1 & 26 & 27 \\
\hline NAZAR & 3 & 7 & 39 & 49 \\
\hline Total & 8 & 11 & 82 & 101 \\
\hline
\end{tabular}

Sumber: Hasil olah data penelitian, 2018

Peningkatan partisipasi residen pada ke 3 (partisipasi konsultatif) terjadi di panti rehabilitasi narkoba menggunakan model Narcotic Anonymous (Yamimas dan PSE Caritas) setelah 2-3 minggu dari tahap ke 3 dimulai, dan di panti rehabilitasi menggunakan model Teurapetic Communnity (Loka BNN dan IPWL Nazar) terjadi pada setelah 2-3 minggu dari tahap ke 3 dimulai. Artinya tidak ada perbedaan signifikan perkembangan partisipasi residen pada tahap ke 3 (partisipasi konsultatif) antara panti rehabilitasi narkoba menggunakan model Narcotic Anonymous 
(Yamimas dan PSE Caritas) dan panti rehabilitasi menggunakan model Teurapetic Communnity (Loka BNN dan IPWL Nazar). Yang perlu menjadi perhatian adalah waktu yang dibutuhkan pada tahap ke 3 ini tergolong lama yaitu 2-3 minggu dari tahap ke 3 dimulai, hal ini tidak menjadi masalah serius bagi panti yang menjadwalkan program minimal 6 bulan di panti rehabilitasi narkoba, namun akan menjadi permasalahan tersendiri bagi panti yang menjadwalkan program selama 3 bulan di panti rehabilitasi narkoba baik menggunakan model Narcotic Anonymous dan atau model Teurapeutic Communnity.

Tabel 6. Tahap 4. Responden mendapatkan hadiah/reward, pujian jika melakukan perbuatan baik selama mengikuti program TC/NA

\begin{tabular}{lcc}
\hline \multicolumn{1}{c}{ Keterangan } & Frekuensi & Persen \\
\hline Tidak Menjawab & 3 & 2.6 \\
\hline Kurang Setuju & 17 & 14.9 \\
\hline Setuju & 94 & 82.5 \\
\hline Total & 114 & 100.0
\end{tabular}

Sumber: Hasil olah data penelitian, 2018

Pada tahap ke 4 (Partisipasi insentif) dari tabel di atas dapat dilihat bahwa mayoritas responden sebanyak 94 orang atau $82,5 \%$ menyatakan setuju bahwa responden mendapatkan hadiah/reward, baik berupa barang atau pujian jika melakukan perbuatan baik selama mengikuti program di panti rehabilitasi narkoba baik menggunakan program Teurapetic Communnity (TC) maupun Narcotic Anonymous (NA). Hal ini menggambarkan bahwa pada tahap 4 (Partisipasi insentif) setiap residen yang melakukan perbuatan baik akan diberi hadiah begitu juga sebaliknya jika ada residen yang tidak patuh atau berperilaku buruk akan diberikan sanksi oleh pekerja sosial/konselor.

Hasil penelitian tersebut didukung oleh hasil wawancara peneliti dengan informan kunci sebagai berikut:

"Setahu saya ada dikasih hadiah kepada residen yang disiplin, berbuat baik. Dan ada juga hukuman kepada yang malas tidak disiplin. Biasanya hadiahnya souvenir barang kebutuhan sehari-hari seperti sabun mandi, handuk, kalau hukumannya seperti menyapu, membersihkan kamar mandi. Tujuannya untuk memberikan disiplin kepada residen selama mengikuti program rehabilitasi narkoba di panti kita"

Menurut informan kunci lainnya sebagai berikut:

"Ada itu dikasih barang-barang bagi mereka yang rajin, terlebih lagi pujian kalau mereka berbuat baik. Nanti diumumkan pada sesi tertentu biar memberikan motivasi bagi residen lainnya untuk disiplin dan berbuat baik lagi."

Menurut informan kunci lainnya sebagai berikut:

"Reward atau hadiahnya bukanlah barang mewah kita kasih kayak coklat, permen, kadang rokok tapi tidak banyak ya. Hanya sebagai stimulus kepada mereka untuk berbuat baik. Untuk rokok ini agak sulit kita melarangnya karena sudah menjadi candu bagi mereka, sehingga di panti rehabilitasi sekalipun rokok ini masih beredar luas Cuma kita batasi kepada residen satu hari maksimal 6 batang."

Tabel 7/Tahap 5. Residen dapat membuat keputusan bersama anggota kelompok dan atau konselor/peksos/petugas panti mengenai kegiatan yang akan dilakukan dengan kegiatan tertentu

\begin{tabular}{lcc}
\hline Keterangan & Frekuensi & Persen \\
\hline Tidak Menjawab & 53 & 46.5 \\
\hline Kurang Setuju & 6 & 5.3 \\
\hline Setuju & 10 & 8.8 \\
\hline Total & 45 & 39.5 \\
\hline
\end{tabular}

Sumber: Hasil olah data penelitian, 2018

Pada tahap ke 5 (partisipasi fungsional) dari tabel di atas dapat dilihat bahwa mayoritas responden tidak menjawab sebanyak 53 atau $46,5 \%$ sedangkan sebanyak 45 orang atau 39,5\% menyatakan setuju bahwa responden dapat membuat keputusan bersama anggota kelompok mengenai kegiatan yang akan dilakukan di panti rehabilitasi narkoba baik menggunakan program Therapeutic Communnity (TC) maupun Narcotic 
Anonymous (NA). Hal ini menggambarkan bahwa pada tahap 5 (partisipasi fungsional) residen diperbolehkan melakukan kegiatan lainnya diluar jadwal program yang telah ditentukan, namun kegiatan tersebut haruslah kegiatan positif yang dapat membantu rsiden pulih dari ketergantungan narkoba dan fokus mengikuti kegiatan di panti rehabilitasi seperti bebas menentukan kegiatan olahraga atau rekreasi ke tempat yang residen suka dilakukan untuk merangsang, menumbuhkan kebiasaan, memotivasi residen selama mengikuti kegiatan atau program di panti rehabilitasi dan setelah keluar dari panti rehabilitasi terbiasa melakukan perbuatanperbuatan baik dan disiplin.

Hasil penelitian tersebut didukung oleh hasil wawancara peneliti dengan informan kunci sebagai berikut:

"Kita memberikan kebebasan kepada anak -anak disini untuk memilih kegiatan yang mereka suka tentunya kegiatan positif"

Menurut informan kunci lainnya sebagai berikut:

"selama kegiatan tersebut tidak melanggar aturan panti dan tidak menghambar proses pemulihan ketergantungan narkoba, saya rasa tidak ada masalah"

Menurut informan kunci lainnya sebagai berikut:

"Agak sulit bagi kita jika jangka waktu kita terbatas (3 bulan) untuk memberikan kebebasan kepada residen menentukan kegiatan yang mereka suka, karena kita memiliki SOP yang harus kita terapkan sesuai dengan jangka waktu pemulihan di panti kita, tapi kalau kegiatan yang dilakukan tersebut mendukung program kita dan tidak terkendala dengan masalah lainnnya seperti anggaran saya rasa tidak ada masalah seperti kegiatan kerohanian yang membantu pemulihan pecandu narkoba untuk pulih dengan mendekatkan diri kepada Tuhan YME, residen ada yang meminta kebaktian dilakukan di gereja ya tidak ada masalah kita ikuti keinginan mereka, karena selama ini kita yang mendatangkan pendeta atau pastor untuk kegiatan rohani tersebut"

Tabel 8. Nama Panti * Residen dapat membuat keputusan bersama anggota kelompok dan atau konselor/peksos/petugas panti mengenai kegiatan yang akan dilakukan dengan iain tertentu Crosstabulation

Pada saat awal masuk responden mengikuti semua perintah konselor tanpa diberikan hak untuk bertanya

\begin{tabular}{lccccc}
\hline Panti & $\begin{array}{c}\text { Tidak } \\
\text { Menjaw } \\
\mathrm{ab}\end{array}$ & $\begin{array}{c}\text { Tidak } \\
\text { Setuju }\end{array}$ & $\begin{array}{c}\text { Kurang } \\
\text { Setuju }\end{array}$ & & \\
\hline YAMIMAS & 0 & 1 & 0 & 6 & 6 \\
\hline CARITAS & 0 & 0 & 0 & 19 & 19 \\
\hline PERMADI & 18 & 0 & 5 & 4 & 27 \\
\hline NAZAR & 33 & 5 & 4 & 7 & 49 \\
\hline Total & 51 & 6 & 9 & 36 & 101 \\
\hline
\end{tabular}

Sumber: Hasil olah data penelitian, 2018

Tabel di atas menggambarkan perbandingan panti rehabilitasi yang menggunakan Model Teurapetic Community (TC) dan Model Narcotics Anonymous (NA) pada tahap 5 (partisipasi fungsional) yang terjadi pada residen, berdasarkan tabel tersebut terlihat perbedaan partisipasi fungsional responden yang dilakukan panti rehabilitasi menggunakan model Narcotic Anonymus (Yayasan Mitra Masyyarakat/YAMIMAS Kota Medan dan PSE Caritas Deliserdang) dari total 25 orang yang setuju responden dapat membuat keputusan bersama anggota kelompok mengenai kegiatan yang akan dilakukan di panti rehabilitasi narkoba sebanyak 25 orang atau $100 \%$.

Untuk panti rehabilitasi Narkotika, Psikotropika dan Obat Terlarang (Narkoba) Model Therapeutic Communnity yaitu Badan Narkotika Nasional (BNN), Insyaf dan Nazar) dari total 36 orang yang menjawab, sebanyak 20 orang atau $55,5 \%$ menjawab setuju, residen yang menjawab kurang setuju sebanyak 10 orang atau $27,8 \%$ dan tidak setuju sebanyak 6 orang atau 16,7\%. Dan sebanyak 53 orang responden tidak menjawab pertanyaan. 
Tabel. 9. Tahap 6 Residen memiliki keperdulian dan bertanggung jawab dengan keputusan bersama yang te lah dibuat

\begin{tabular}{lcc}
\multicolumn{1}{c}{ Keterangan } & Frekuensi & Persen \\
\hline Tidak Menjawab & 53 & 76.8 \\
\hline Kurang Setuju & 6 & 8.7 \\
\hline Setuju & 10 & 14.5 \\
\hline Total & 69 & 100.0 \\
\hline
\end{tabular}

Sumber: Hasil olah data penelitian, 2018

Pada tahap ke 6 (partisipasi interaktif) dari tabel di atas dapat dilihat bahwa mayoritas responden tidak menjawab sebanyak 53 orang atau 76,8\% sedangkan sebanyak 10 orang atau $14,5 \%$ menyatakan setuju bahwa responden memiliki kepedulian dan bertanggung jawab dengan keputusan bersama yang telah dibuat di panti rehabilitasi narkoba baik menggunakan program Therapeutic Community (TC) maupun Narcotic Anonymous (NA). Hal ini menggambarkan bahwa pada tahap 6 (partisipasi interaktif) residen memiliki kepedulian terhadap program, kepedulian terhadap sesama residen lainnya, kepedulian terhadap kesembuhan ketergantungan dari narkoba, dan berparitisipasi dalam tanggung jawab atas keputusan bersama yang telah dibuat. Namun kondisi tersebut belum terwakili dari hasil penelitian yang banyak tidak menjawab atau sebanyak 64 orang atau $56,1 \%$

Kondisi tersebut berbeda dengan residen yang mengatakan kurang setuju sebanyak 12 orang atau 10,5\% dan residen yang menjawab tidak setuju sebanyak 1 orang atau 9,6\%. Hal ini dikarenakan menurut residen yang ada belum terjadi partisipasi pada tahapan 6 atau partisipasi interaktif dimana setiap residen telah memiliki kepedulian yang tinggi dan memiliki tanggung jawab atas keputusan bersama yang telah dibuat sebelumnya oleh seluruh anggota kelompok.

Hasil penelitian tersebut didukung oleh hasil wawancara penelitian sebagai berikut: hasil wawancara peneliti dengan informan kunci sebagai berikut"Kalau menurut saya sudah berjalan dengan baik, mungkin memang belum maksimal soal tanggung jawab tersebut"Menurut informan kunci lainnya sebagai berikut:

"Kepedulian mereka sesama residen saya lihat cukup baik, dan sudah adalah tanggung jawabnya walaupun belum dikatakan maksimal, karena memang agak susah kalau kita berikan kepada mereka tanggung jawab yang besar.

Menurut informan kunci lainnya sebagai berikut:

"Tujuan kita salah satunya adalah mereka para residen memiliki tanggung jawab minimal terhadap diri mereka sendiri yaitu tidak lagi menggunakan narkoba, dan memiliki tanggung jawab mengikuti seluruh kegiatan selama di panti rehabiltiasi narkoba ini".

Tabel 10. Nama Panti * Residen/kelompok dapat menentukan sendiri kegiatan yang akan dilakukan secara mandiri dalam mengikuti program TC/NA tanpa persetujuan konselor/peksos/petugas panti Crosstabulation

Pada saat awal masuk responden mengikuti [otal semua perintah konselor tanpa diberikan

hak untuk bertanya

\begin{tabular}{lccccccc}
\hline Panti & 2 & 1 & 0 & 3 & 0 & 0 & 6 \\
Rehabilitasi & & & & & & & \\
YAMIMAS & 2 & 1 & 1 & 15 & 0 & 0 & 19 \\
CARITAS & 1 & 0 & 0 & 26 & 0 & 0 & 27 \\
PERMADI & 3 & 1 & 2 & 42 & 1 & 0 & 49 \\
NAZAR & 7 & 3 & 1 & 1 & 0 & 1 & 13 \\
\hline Total & 15 & 6 & 4 & 87 & 1 & 1 & 114 \\
\hline
\end{tabular}

Sumber: Hasil olah data penelitian, 2018

Peningkatan partisipasi residen pada Pada tahap ke 7 (mandiri/self mobilizatio n) terjadi di panti rehabilitasi narkoba menggunakan model Narcotic Anonymous (Yamimas dan PSE Caritas) setelah 2-3 minggu dari tahap ke 7 dimulai, dan di panti rehabilitasi menggunakan model Teurapetic Communnity (Loka BNN dan IPWL Nazar) terjadi pada setelah 2-3 minggu dari tahap ke 7 dimulai. Artinya tidak ada perbedaan signifikan perkembangan partisipasi residen pada tahap ke 7 (mandiri/self mobilization) antara panti rehabilitasi narkoba menggunakan model Narcotic Anonymous (Yayasan Masayarakat Mitra Sejahtera/Yamimas Kota Medan dan PSE 
Caritas Deliserdang) dan panti rehabilitasi menggunakan model Therapeutic Communnity (Loka Badan Narkotika Nasional (BNN)) Deliserdang dan Yayasan Nazar Kota Medan). Yang perlu menjadi perhatian adalah waktu yang dibutuhkan pada tahap ke 7 ini tergolong lama yaitu 2-3 minggu dari tahap ke 7 dimulai, hal ini tidak menjadi masalah serius bagi panti yang menjadwalkan program minimal 6 bulan atau lebih di panti rehabilitasi narkoba, namun akan menjadi permasalahan tersendiri bagi panti yang menjadwalkan program selama 3 bulan di panti rehabilitasi narkoba baik menggunakan model Narcotic Anonymous dan atau model Thrapeutic Communnity.

\section{SIMPULAN}

Terdapat perbedaan signifikan tingkatan partisipasi residen yaitu pada tahapan Partisipasi Fugsional yang dilakukan panti rehabilitasi Model Therapeutic Community (TC) 55,5"\%, sedangkan panti rehabilitasi yang menggunakan Model Narcotic Anonymous (NA) adalah 100\%, pada tahap ini perbedaan sangat signifikan sebesar 44,5\%, dan Partisipasi Interaktif menggunakan di panti rehabilitasi yang mengguakan Model Therapeutic Community (TC) 65,4"\%, sedangkan panti rehabilitasi yang menggunaan Model Narcotic Anonymous (NA) adalah 44\%, pada tahap ini terjadi perbedaan sebesar $21,5 \%$

\section{UCAPAN TERIMAKASIH}

Terimakasih peneliti ucapkan kepada LEMBAGA PENELITIAN UNIVERSITAS SUMATERA UTARA Dengan Nomor Kontrak:2950/UN5.1.R/PPM/2018 tanggal 18 Maret 2018. Dalam skema PENELITIAN DOSEN MUDA TAHUN 2018 yang telah memberikan dana penelitian sehingga penelitian ini dapat dilakukan dan dipublikasi.

\section{DAFTAR PUSTAKA}

Adi, I. R. (2012). Intervensi Komunitas Pengembangan Masyarakat Sebagai Upaya Pemberdayaan Masyarakat. Jakarta: Raja Grafindo

Espinosa, A.H.R. Estevezb, A.G. Figarola, Y, M, Rodriguez, D.L. (2018). Psychological Intervention for Development of Disease Awareness in Addicts: Villa Colibri Therapeutic Community of Santiago de Cuba. International Journal of Health Sciences Available online at http://sciencescholar.us/journal/index.php/ ijhs Vol. 2 No. 3, December 2018, pages: 72 80 e-ISSN: 2550-696X, p-ISSN: 25506978

https://doi.org/10.29332/ijhs.v2n3.232. diakses pada 6 Juni 2018., pukul 15.30 W.I.B

Gunawan, S. \& Roebiyanto, H, (2014), Eksistensi Rehabilitasi Sosial Berbasis Masyarakat bagi Korban Penyalahgunaan Napza. Jakarta: P3KS press.

Halgin, R.P \& Whitbourne, S.K. (2010). Psikologi Abnormal (Perspektif Klinis Pada Gangguan Psikologis). Jakarta: Salemba Humanika.

Herlina, Y. (2016) Therapeutic Community Sebagai Metode Komprehensif. Dapat diakses pada laman

https://galihpakuan.kemsos.go.id/modules.ph p?name $=$ News\&file $=$ print $\&$ sid $=106 . \quad$ diakses pada 6 Juni 2018., pukul 15.30 W.I.B

Husaini, E.F. \& Adenan. (2016) Pendekatan Metode Narcotics Anonymous Dalam Pemulihan Korban Penyalahgunaan Narkoba Di Yayasan Lingkaran Harapan Banua Banjarmasin. Jurnal: Jurnal Berkala Kesehatan, Vol. 1, No. 2, Mei 2016: 96-105

Deny, K. Ratna, Y. \& Ari, H. (2017). "Hubungan antara Keadaan Keluarga Dengan Perilaku Relapse (Kekambuhan) Narkoba Pada Residen. Jurnal Kesehatan Masyarakat. Universitas Muhammadiyah Kalimantan Timur. Volume 7, Nomor 2, Desember 2017.

Maharani, S.D. (2018). "Efektivitas Program Therapeutic Community (TC) Dalam Mengubah Perilaku Pengguna Napza di Lembaga Rehabilitasi Pencegahan Penyalahguna Narkotika (LRPPN) Bhayangkara Indonesia di Kota Medan. Skripsi: Kesejahteraan Sosial FISIP USU.

Meleong, L.J. (2010). Metode Penelitian Kuantitatif (Edisi Revisi). Bandung: PT Remaja Rosdakarya.

Muhidin, (2012). Pelayanan Kesejahteraan Sosial. Jakarta: PT. Graha Insan

Neuman, W.L. (2006). Social Research Methode: Qualitative and Quantitative Approach (Sixth Edition). Needham Heights. MA: Allyn \& Bacon. 
Pimansu, (2010). Narcotics Anonymous (NA) di akass pada laman: http://pimansupimansu.blogspot.com/2010/04/narcoticsanonymous-na.html, diakses pada 6 Juni 2018., pukul 15.30 W.I.B.

Sugiyono. (2009). Metode Penelitian Kuatitatif, Kualitatif dan R\&D. Bandung: CV. Alfabeta
Syahyuti. (2016). Strategi dan Tantangan dalam Pengembangan Gabungan Kelompok Tani (Gapoktan) sebagai Kelembagaan Ekonomi di Pedesaan. Jurnal: Pusat Analisis Sosial Ekonomi dan Kebijakan Pertanian. Bogor: IPB Press 